\title{
PENGARUH STRUKTUR MODAL TERHADAP KINERJA PERUSAHAAN PADA PT. ASTRA INTERNATIONAL, TbK
}

\author{
Dwi Rizki Sandria, Riandani Rezki Prana, Wardayani \\ Alumni Sekolah Tinggi Ilmu Manajemen Sukma \\ Program studi Manajemen, Sekolah Tinggi Ilmu Manajemen \\ riandanirezki@,gmail.com, wardayani302@,gmail.com
}

\begin{abstract}
The purpose of this study is to determine the effect of capital structure on corporate performance Population of this study is the financial statements of PT. Astra International Tbk listed on Indonesia Stock Exchange 2009-2016. This research is quantitative descriptive research to know influence of capital structure to company performance. The data collection instrument uses direct documentation and observation which is then analyzed using simple linear regression. Data analysis using simple linear regression test, hypothesis test using SPSS 20. The result obtained is capital structure have positive and significant effect to company performance.
\end{abstract}

Keywords: capital structure and company performance

\section{PENDAHULUAN}

Pada dasarnya tugas manager keuangan perusahaan adalah berusaha mencari keseimbangan financial neraca yang dibutuhkan serta mencari susunan kualitatif neraca tersebut dengan sebaik-baiknya,pemilihan susunan kualitatif pada sisi assets akan menentukan struktur kekayaan perusahaan sedangkan pemillihan susunan kualitatif dari sis liabilities dan equities akan menentukan struktur keuangan dan struktur modal perusahaan, perusahaan sabagai salah satu bentuk organisasi pada umumnya memiliki tujuan tertentu yang ingin dicapai dalam usaha untuk memenuhi kepentingan anggotanya,kinerja perusahaan merupakan suatu gambaran tentang kondisi keuangan suatu perusahaan yang dianalisis dengan alat-alat analisis keuangan,sehingga dapat diketahui mengenai baik buruknya keadaan keuangan suatu perusahaan yang mencerminkan prestasi kerja dalam priode tertentu.

Penelitian yang dilakukan oleh Suandini dan Suzan (2015) dengan judul Pengaruh Struktur Modal Terhadap Kinerja Keuangan Perusahaan (Studi Kasus Pada Perusahaan Industri Barang Konsumsi Yang Terdaftar Di Bursa Efek Indonesia) menyatakan bahwa DAR tidak berpengaruh dengan arah negative terhadap kinerja keuangan, DER tidak berpengaruh dengan arah positif terhadap kinerja keuangan, LDER berpengaruh negative terhadap kinerja keuangan, dan TIER berpengaruh positif terhadap kinerja keuangan. Penelitian yang dilakukan oleh Romadhoni dan Sunaryo (2015) dengan judul Pengaruh Struktur Modal Terhadap Kinerja Keuangan Perusahaan Manufaktur Sektor Makanan Dan Minuman Yang Terdaftar Di Bursa Efek Indonesia Tahun 2013-2016 menyatakan bahwa Debt Equity Ratio memiliki nilai t hitung 2,472 (sig. 0,017<0,05) Debt to Asset Ratio memiliki nilai t hitung 0,965 (sig. 0,340>0,05) Equity to Asset Ratio memiliki nilai thitung 0,942 (sig. 0,351>0,05) yang menunjukkan bahwa Debt Equity Ratio secara parsial berpengaruh positif signifikan, Debt to Asset Ratio dan Equity to Asset Ratio secara parsial berpengaruh tidak signifikan terhadap Equity to Asset Ratio, serta bersama-sama Debt Equity Ratio, Debt to Asset Ratio dan Equity to Asset Ratio berpengaruh positif signifikan terhadap Return on Equity, dibuktikan dengan besar F hitung 3,444 (sig. 0,008<0,05). 


\section{Perumusan Masalah}

Berdasarkan latar belakang diatas, maka penelitian ini dapat dirumuskan Apakah ada pengaruh struktur modal kerja terhadap kinerja perusahaan pada PT. Astra International, Tbk yang terdaftar di bursa efek indonesia.

\section{Batasan Masalah}

Mengingat adanya keterbatasan waktu dan kemampuan penulis, maka penelitian ini hanya dibatasi pada laporan keuangan PT. Astra International Tbk yang terdaftar di Bursa Efek Indonesia pada priode 2009-2016. Indikator yang digunakan berupa rasio Net Profit Margin dan Return On Equity .

\section{Tujuan Penelitian}

Adapun tujuan dari penelitian ini adalah untuk mengetahui apakah ada pengaruh struktur modal terhadap kinerja keuangan pada PT. Astra International, Tbk yang terdaftar di bursa efek Indonesia.

\section{METODE PENELITIAN}

\section{Metode Analisis Data}

Metode analisis data yang digunakan dalam penelitian ini adalah metode deskriptif kuantitatif, sedangkan model analisis yang digunakan dalam penelitian ini adalah regresi linier sederhana, dengan model persamaan:

Dimana:

$$
\mathrm{Y}=\mathrm{a}+\mathrm{bx}+\mathrm{e}
$$

$$
\begin{array}{ll}
\mathrm{Y} & =\text { Kinerja Perusahaan } \\
\mathrm{X} & =\text { Struktur Modal } \\
\mathrm{a} & =\text { Konstanta } \\
\mathrm{b} & =\text { Koefisien regresi variabel struktur modal } \\
\mathrm{e} & =\text { Error of term (variabel yang tidak diteliti) }
\end{array}
$$

\section{Kerangka Berpikir}

Struktur modal adalah pembiayaan permanen yang terdiri dari hutang jangka panjang, saham preferen dan modal pemegang saham. Kinerja adalah nilai dari seperangkat prilaku karyawan yang berkontribusi, baik secara positif atau negatif terhadap pemenuhan tujuan organisaasi. Hasil penelitian Rahayu dan Setiana (2014) Hasil penelitian menunjukkan bahwa struktur modal (DER) memengaruhi semua variabel kinerja keuangan yang digunakan (ROA, ROE, LDR) dengan tingkat signifikansi masing-masing lebih kecil dari 5\%.

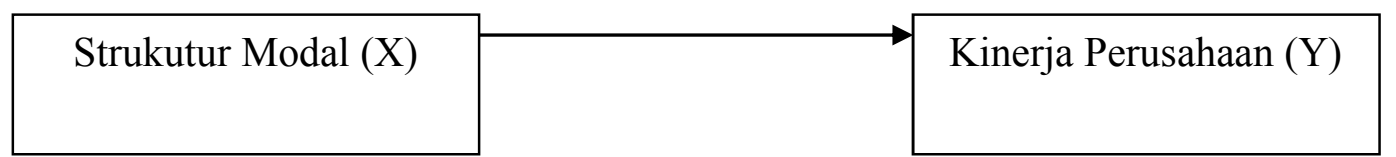

Gambar 1. Kerangka Berfikir

Sumber: Rahayu dan Setiana (2014)

\section{Hipotesis}

"Hipotesis merupakan pernyataan sederhana mengenai suatu harapan peneliti tentang hubungan antarvariabel dalam masalah" (Dantes, 2012:28)

Formulasi hipotesis penelitian ini adalah: 
Jika $t_{\text {hitung }} \leq t_{\text {tabel }}$ maka $\mathrm{H}_{0}$ diterima, $\mathrm{H} 1$ ditolak, artinya secara parsial struktur modal tidak berpengaruh terhadap kinerja keuangan, sedangkan jika $t_{\text {hitung }}>t_{\text {tabel }}$ maka $\mathrm{H}_{0}$ ditolak, $\mathrm{H} 1$ diterima, artinya secara parsial struktur modal berpengaruh terhadap kinerja perusahaan.

Berdasakan formulasi diatas, maka hipotesis penelitian ini adalah: "Ada pengaruh struktur modal terhadap kinerja perusahaan pada PT. Astra International Tbk, “

\section{Pengujian Hipotesis}

a. Koefisien Determinasi $\left(\mathrm{R}^{2}\right)$

Koefisien determinasi $\left(\mathrm{R}^{2}\right)$ pada intinya mengukur seberapa besar kemampuan model dalam menerangkan variabel terikat. Semakin besar nilai koefisien determinasi (mendekati satu), maka dapat dikatakan bahwa pengaruh variabel bebas (X) adalah besar terhadap variabel terikat $(\mathrm{Y})$.

b. Uji Parsial (Uji t)

Uji parsial (Uji t) bertujuan untuk melihat pengaruh struktur modal kerja terhadap kinerja perusahaan, dengan kriteria:

1. Jika $t_{\text {hitung }} \leq t_{\text {tabel }}$ maka $\mathrm{H}_{0}$ diterima, $\mathrm{H} 1$ ditolak, artinya secara parsial penelitian tidak ada pengaruh;

2. Jika $t_{\text {hitung }}>\mathrm{t}_{\text {tabel }}$ maka $\mathrm{H}_{0}$ ditolak, $\mathrm{H} 1$ diterima, artinya secara parsial penelitian terdapat pengaruh (berpengaruh).

\section{HASIL DAN PEMBAHASAN}

\section{Hasil Uji Regresi Sederhana}

Untuk mengetahui pengaruh struktur modal terhadap kinerja perusahaan pada PT. Astra International Tbk di bursa efek Indonesia priode tahun 2009 - 2016, maka digunakan uji regresi linear sederhana. Berikut adalah table hasil pengujian masing-masing variabel.

Tabel 1. Hasil Pengujian Regresi

Coefficients $^{a}$

\begin{tabular}{|c|c|c|c|c|c|c|}
\hline \multirow{2}{*}{\multicolumn{2}{|c|}{ Model }} & \multicolumn{2}{|c|}{$\begin{array}{l}\text { Unstandardized } \\
\text { Coefficients }\end{array}$} & \multirow{2}{*}{$\begin{array}{c}\begin{array}{c}\text { Standardized } \\
\text { Coefficients }\end{array} \\
\text { Beta } \\
\end{array}$} & \multirow[t]{2}{*}{$\mathrm{t}$} & \multirow[t]{2}{*}{ Sig. } \\
\hline & & $B$ & Std. Error & & & \\
\hline \multirow[b]{2}{*}{1} & (Constant) & 123 &, 019 & & 6,361 &, 000 \\
\hline & $\begin{array}{l}\text { STRUKTUR } \\
\text { MODAL }\end{array}$ & 179 & ,085 & ,408 & 2,098 & ,048 \\
\hline
\end{tabular}

a. Dependent Variable: KINERJA PERUSAHAAN

berikut :

Berdasarkan hasil pengujian diatas maka diperoleh persamaan regresi sebagai

$$
\mathbf{Y}=\mathbf{0 , 1 2 3}+\mathbf{0 , 1 7 9} \mathrm{X}
$$

Persamaan regresi diatas dapat dijelaskan bahwa nilai konstanta kinerja perusahaan sebesar 0,123 artinya bahwa jika nilai variabel bebas $(\mathrm{X})$ nilainya 0 maka variabel terikat $(\mathrm{Y})$ nilainya sebesar 0,123 . Koefisien regresi variabel bebas $\mathrm{X}$ bernilai positif artinya bahwa kinerja perusahaan pada PT. Astra International Tbk di bursa efek Indonesia priode tahun 2009 - 2016 berpengaruh positif dan tidak signifikan pada kinerja perusahaan . 


\section{Pengujiaan Hipotesis}

a. Koefisian Determinasi (R2)

Koefisian Determinasi (R2) bertujuan untuk mengukur berapa besar pengaruh variabel X terhadap Y. Nilia Koefisien Determinasi (R2) dapat dilihat dari table berikut :

Tabel 2. Uji Koefisien Deterninasi $\left(\mathrm{R}^{2}\right)$

Model Summary

\begin{tabular}{|l|r|r|r|r|}
\hline Model & R & R Square & Adjusted R Square & \multicolumn{1}{|c|}{$\begin{array}{c}\text { Std. Error of the } \\
\text { Estimate }\end{array}$} \\
\hline 1 &, $408^{\mathrm{a}}$ &, 167 &, 129 &, 05128 \\
\hline
\end{tabular}

a. Predictors: (Constant), STRUKTUR MODAL

Berdasarkan tabel diatas Nilai Koefisien Determinasi (R2) diperoleh sebesar 0,167 atau $16,7 \%$ menunjukan bahwa variabel struktur modal mampu menjelaskan variasi yang terjadi pada kinerja perusahaan PT. Astra International Tbk di bursa efek Indonesia, sedangkan sisanya 0,833 atau $83,3 \%$ dijelaaskan oleh variabel yang tidak diteliti dalam penelitian ini.

\section{b. Uji Parsial}

Uji Parsial (uji t) betujuan untuk melihat pengaruh struktur modal terhadap kinerja perusahaan, dengan kriteria :

1. Jika thitung $<$ ttabel maka $\mathrm{H} 0$ diterima, $\mathrm{H} 1$ ditolak, artinya secara parsial penelitian ini tidak berpengaruh;

2. Jika thitung $>$ ttabel maka $\mathrm{H} 0$ ditolak, $\mathrm{H} 1$ diterima, artinya secara parsial penelitian ini berpengaruh;

Tabel 3. Hasil Uji Parsial (Uji t)

Coefficients $^{\mathrm{a}}$

\begin{tabular}{|c|c|c|c|c|c|c|}
\hline \multirow{2}{*}{\multicolumn{2}{|c|}{ Model }} & \multicolumn{2}{|c|}{$\begin{array}{l}\text { Unstandardized } \\
\text { Coefficients }\end{array}$} & \multirow{2}{*}{$\begin{array}{c}\text { Standardized } \\
\text { Coefficients } \\
\text { Beta }\end{array}$} & \multirow[t]{2}{*}{$\mathrm{T}$} & \multirow[t]{2}{*}{ Sig. } \\
\hline & & $B$ & Std. Error & & & \\
\hline \multirow[b]{2}{*}{1} & (Constant) & ,123 & ,019 & & 6,361 & ,000 \\
\hline & $\begin{array}{l}\text { STRUKTUR } \\
\text { MODAL }\end{array}$ & 179 & ,085 & ,408 & 2,098 & ,048 \\
\hline
\end{tabular}

a. Dependent Variable: KINERJA PERUSAHAAN

Nilai $t_{\text {hitung }}<t_{\text {tabel }}(2,098<2,045)$ dan signifikan $0,048>$ dari nilai alpha $(0,05)$, maka $\mathrm{H} 0$ ditolak dan $\mathrm{H} 1$ diterima, dengan demikian secara parsial struktur modal kerja berpengaruh positif dan tidak signifikan terhadap kinerja perusahaan.

\section{Pembahasan}

1. Hasil pengujian hipotesis pertama menunjukkan bahwa struktur modal kerja berpengaruh positif dan signifikan terhadap kinerja perusahaan, hal ini dibuktikan dengan nilai Nilai $t_{\text {hitung }}<t_{\text {tabel }}(2,098<2,045)$ dan signifikan $0,048<$ dari nilai alpha $(0,05)$. Hasil penelitian ini sesuai dengan hasil penelitian oleh Rosalinawani (2015) yang berjudul Pengaruh Struktur Modal Terhadap Kinerja Perusahaan yang Terdaftar di BEI 2013,. 
2. Hasil pengujian determinasi disimpulkan bahwa diatas Nilai Koefisien Determinasi (R2) diperoleh sebesar 0,167 atau 16,7\% menunjukan bahwa variabel struktur modal mampu menjelaskan variasi yang terjadi pada kinerja perusahaan PT. Astra International Tbk di bursa efek Indonesia, sedangkan sisanya 0,833 atau 83,3\% dijelaaskan oleh variabel yang tidak diteliti dalam penelitian ini.

3. Hasil penelitianoleh Rahayudan Setiana (2012)menunjukan bahwa struktur modal berpengaruh negative dan signifikanterhadap kinerja. Nilai R square adalah 0,192 atau $19,2 \%$ dapat dijelaskan oleh valiabel bebas dalam penelitian ini sedangkan sisanya sebesar $80,8 \%$ dijelaskan oleh variabel yangtidak diteliti.

\section{Kesimpulan}

Berdasarkan hasil penelitian dan pembahasan mengenai pengaruh struktur modal terhadap kinerja perusahaan pada PT. Astra International Tbk, maka penulis dapat menyimpulkan sebagai berikut :

Secara parsial variabel struktur modal berpengaruh positif dan signifikan terhadap variabel kinerja perusahaan pada PT. Astra International, Tbk. 


\section{REFERENCES}

Batubara, A., \& Hidayat, R. (2016). Pengaruh Penetapan Harga dan Promosi terhadap Tingkat Penjualan Tiket pada PSA Mihin Lanka Airlines. Jurnal Ilman, 4(1), 33-46.

Cece. (2003). Analisis Hubungan Perencanaan Strategi Aliansi PDAM Tirtanadi-PT. Telekominikasi Divre I Terhadap Peningkatan Kualitas Pelayanan Pelanggan PDAM Tirtanadi... Universitas Sumatera Utara.

Dantes. (2012). Metodologi Penelitian. Yogyakarta.

Dewi, S. P., \& Hidayat, R. (2014). Pengaruh Net Profit Margin dan Return on Assets terhadap Harga Saham pada Perusahaan Otomotif yang terdaftar di Bursa Efek Indonesia. Jurnal Ilman, 1(1), 110 .

Dinamika, S. G. (2018). Gemstone Fever Hits Jakarta: A Lexical Meaning Analysis.

Dinamika, Soraya Grabiella (2014) THE EFFECT OF USING COLLABORATIVE STRATEGIC READING ON STUDENTS' ACHIEVEMENT IN READING NARRATIVE TEXT. Undergraduate thesis, UNIMED

Fahmi, I. (2014). Manajemen Keuangan dan Pasar Modal (Pertama). Jakarta.

Fathimah, V. (2017). Pengaruh Perkembangan Jumlah Tabungan, Deposito dan Bagi Hasil terhadap Jumlah Pembiayaan yang Diberikan oleh Perbankan Syariah di Sumatera Utara. Jurnal Ilman, $5(1), 41-52$.

Hery. (2012). Analisis Laporan Keuangan. (Sutini, Ed.) (Pertama). Jakarta: Bumi Aksara.

Hidayat, R. (2015). Performance Appraisal sebagai Alat Pengukuran Kepuasan Kerja Karyawan. Jurnal Ilman, 3(1), 1-8.

Kasmir. (2016). Analisis Laporan Keuangan (Pertama). Jakarta: PT. Rajagrapindo Persada.

Nasution, W. A. (2009). Pengaruh kepuasan kerja karyawan terhadap intensi turnover pada call center Telkomsel di Medan. Jurnal Mandiri, 4(1), 1-11.

Nasution, W. A. (2013). Pengaruh kompensasi dan lingkungan kerja terhadap kepuasan kerja karyawan pada PT. Karya Deli Stelindo Medan. Jurnal Manajemen Bisnis STIE IBBI, 20(2), 177.

Ningratri, Y. A. (2017). Analisis Pengaruh Strategi Bauran Pemasaran Jasa (3P) terhadap Keputusan Mahasiswa Memilih STIM Sukma Medan. Riset \& Ejurnal Manajemen Informatika, 3(1), 5056.

Prana, R. R. (2016). Analisis Faktor-faktor yang Mempengaruhi Pendapatan Asli Daerah (PAD) Kota Tebing Tinggi. Jurnal Ilman, 4(1), 74-86.

Rahayu, D., \& Setiana, E. (2012). Analisis Pengaruh Struktur Modal Terhadap Kinerja Pada Perusahaan Otomotif Yang Terdaftar di BEI Tahun 2008-2010.

Raidani, Pertiwi, L. S., Wulandari, D. Y., \& Zuhri. (2016). Tobit and Interval Censored Regression Model. Global Journal of Pure and Applied Mathematics, 12(1), 981-994.

Romadhoni, \& Sunaryo, H. (2016). PENGARUH STRUKTUR MODAL TERHADAP KINERJA KEUANGAN PERUSAHAAN MANUFAKTUR SEKTOR MAKANAN DAN MINUMAN YANG TERDAFTAR DI BURSA EFEK INDONESIA TAHUN 2013-2016, 444, 219-233. 
Rosalinawati. (2015). PENGARUH STRUKTUR MODAL TERHADAP KINERJA PERUSAHAAN YANG TERDAFTAR DI BURSA EFEK INDONESIA TAHUN 2013.

Safriandi, F., Pertiwi, L. S., Fitriani, A., \& Zuhri. (2016). Truncated Regression Model and Nonparametric Estimation for Gifted and Talented Education Program. Global Journal of Pure and Applied Mathematics, 12(1), 995-1002.

Sinaga, S., Pertiwi, L. S., Ardian, T., \& Zuhri. (2016). Inventory Simulation Optimization Under Non Stationary Demand. International Journal of Applied Engineering Research, 11(1), 524-529.

Sinuhaji, E. (2010). PENERAPAN LAYANAN UNGGUL DALAM PEMASARAN PRODUK BANK. Jurnal Mediasi, 2(1).

Sinuhaji, E. (2013). PENGARUH BUDAYA ORGANISASI TERHADAP KEPUASAN KERJA KARYAWAN PADA JASA PERHOTELAN (Studi Kasus di Garuda Plaza Hotel Medan). Bisnis Administrasi, 2(1), 2537.

Sinuhaji, E. (2014). Pengaruh Kepribadian, Kemampuan Kerja dan Motivasi Kerja terhadap Kinerja SDM Outsourcing pada PT. Catur Karya Sentosa Medan. Jurnal Ilman, 1(1), 11-22.

Suandini, K., \& Suzan, L. (2015). PENGARUH STRUKTUR MODAL TERHADAP KINERJA KEUANGAN PERUSAHAAN (Studi Kasus pada Perusahaan Industri Barang Konsumsi yang Terdaftar di Bursa Efek Indonesia) The Impact of the Capital Structure on Financial Firm Performance (Evidence from Consumer Good In, 2(1), 211217.

Sujarweni, W. (2015). Akuntansi Sektor Publik (Pertama). Yogyakarta: Pustaka Baru Press Yogyakarta.

Sukendro, H. A. (2012). Pengaruh Citra Merek dan Kualitas Pelayanan terhadap Kepuasan Jama'ah pada Kelompok Bimbingan Ibadah Haji (KBIH) Indosat Medan. Universitas Terbuka.

Utari, D., Purwanti, A., \& Prawironegoro, D. (n.d.). Manajemen Keuangan (Revisi). Jakarta: Mitra Wacana Media.

Wardayani. (2012). ANALISIS PERBANDINGAN KINERJA KEUANGAN DITINJAU DARI SEGI PROFITABILITAS PADA PT. INDOFOOD CBP SUKSES MAKMUR. Jurnal Riset Akuntansi, $1,40-52$.

Wardayani. (2013). Pengaruh Pengetahuan Dewan Tentang Anggaran, Partisipasi Masyarakat dan Transparansi Kebijakan Publik terhadap Kinerja DPRD dalam Pengawasan Keua. Jurnal BIS-A Politeknik LP3i Medan, 2, 35-45.

Wardayani. (2015). ANALISIS KINERJA KEUANGAN PADA PT. SIAR HARAMAIN INT. WISATA MEDAN. Jurnal Bis-A: Jurnal Bisnis Administrasi, 4(2), 14-24.

Widjanarko, B. (2015). PENGARUH PEMERIAN KOMPENSASI DAN KOMUNIKASI TERHADAP SEMANGAT KERJA KARYAWAN PADA BUMI KARYA TAMA INSURANCE CABANG MEDAN. Jurnal Research Sains, 1(2), 130-152.

Winata, E. (2016). Pengaruh Kepuasan Kerja dan Kompensasi terhadap Kinerja Karyawan pada Hotel Inna Dharma Deli Medan. Jurnal Ilman, 4(1), 1-17.

Winata, E. (2016). PENGARUH KOMPENSASI DAN KOMUNIKASI TERHADAP SEMANGAT KERJA KARYAWAN PADA PT. FIF CABANG MEDAN. Jurnal Dunia Ilmu, 2(1), 17-31.

Winata, E. (2017). PENGARUH BAURAN PEMASARAN JASA TERHADAP LOYALITAS KONSUMEN PADA GRAND SERELA HOTEL \& CONVENTION MEDAN. Jurnal Mutiara Manajemen, 1(1), 109-121. 